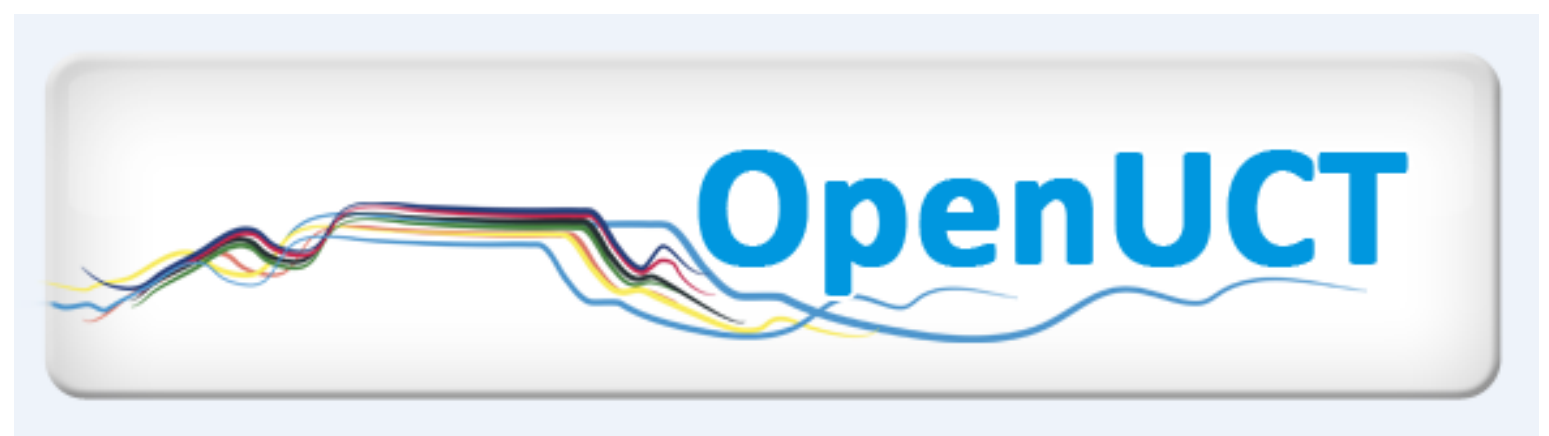

This is the author-approved manuscript version of a journal article published in:

Underwood, P. G. 2009. Supporting the information needs of entrepreneurs in South Africa. International Library Review. 58(8): 569-580. DOI: 10.1108/0024253091098706.

It is made available under the terms of agreement between the author and the journal, and in accordance with the University of Cape Town's Open Access Policy for the purposes of research, teaching and private study.

http://www.openuct.uct.ac.za/sites/default/files/UCTOpenAccessPolicy.pdf 


\title{
Supporting the information needs of entrepreneurs in South Africa
}

\author{
Peter Underwood \\ Department of Information and Library Studies, University of Cape Town, \\ Cape Town, South Africa. Email: Peter.Underwood@uct.ac.za
}

\begin{abstract}
Purpose - The Library Business Corners (LBC) service for entrepreneurs in the Western Cape of South Africa uses public libraries as a channel for information and expertise. It is a "grass roots", community-driven, approach which has been adopted elsewhere in South Africa. Similar services have appeared addressing the same, or similar, groups of users, often concentrating on the use of information and communication technology.

Design/methodology/approach - Developing an effective service for entrepreneurs depends critically on the quality of staff and their contacts. The opportunities and problems of the LBCs' approach are identified and a response to the emergence of similar services is considered. The "balanced score card" model is used to explore the vision and strategy of the present services and the potential contribution of information literacy.

Findings - Financial support for LBC work is scarce and unlikely to increase. The challenge is to create a sustainable service by the LBC team as points of presence, using the existing or reduced financial base. Concentration on increasing capacity at the point of delivery of information through knowledge of the business environment and information literacy is essential.

Originality/value - The paper describes the first application of the "balanced score card" technique to a public library business information service in South Africa.

Keywords: South Africa, Information literacy, Balanced scorecard, Business support services,

Public libraries

Paper type: Case study
\end{abstract}

\section{Background}

The inauguration, in 1994, of the Government of National Unity initiated major changes in the governance of South Africa and its social, education and welfare services. The country has three levels of government which operate independently at national, provincial and local levels, each having legislative and executive authority within its locus of operation. In broad terms the mandate of the government was, and remains, to transform the country into a democratic state, to correct the injustices and inequalities of the past, to alleviate poverty and to promote a better life for all. However, despite the efforts of successive administrations, substantial differences remain between the population groups when access to the basics of life is considered. The huge backlog in human resource development, one of the most disturbing legacies of the apartheid years, is reflected in the Human Development Index rankings, which place South Africa as 125th, in the Medium Development range, out of the 179 countries included in the survey, with an index of 0.670 ; the HPI-1 Index, which measures a group of economic, welfare and social factors, ranks South Africa as 22.6 per cent, making it 81st out of 135 countries classed as "developing" (United Nations Development Programme, 2008). The World Bank Group analysis also indicates that the gap between rich and poor in South Africa is one of the largest in the world: "South Africa is a country with extreme differences in incomes and wealth. Thirteen per cent of the population lives in 'first world' conditions, while nearly 50 per cent lives in developing country conditions"; the World Bank also notes that "While South Africa's success in stabilising the economy is impressive, the low growth in jobs and investment leaves sianificant room for imbrovement" (World Bank Groub. 2008). 
If the social circumstances have been characterised as that of two extremes of society, one being a minority of largely white, affluent, people and the other characterised by poverty and underdevelopment, there is some recent evidence that the gap between them is beginning to narrow. Of the population of 47.4 million (2006 midyear estimate), a recent study has indicated a strong increase in the black middle class, which is estimated to have grown in 2006 from 2.0 million to 2.6 million people, an increase of 30 per cent for the year, with a collective spending power of 180 billion Rands (Brand South Africa, 2007), or approximately £146.3 million at the average exchange rate in 2006. A study in the same year suggested that the benefits of Black Economic Empowerment (BEE) policy have yet to be realised at a broad community level (University of Cape Town, 2006), a finding that serves to underline some of the complexities of the South African culture and economy and the length of time that realignment of the economy may take. The turmoil in the world economy from late 2008 onwards will affect the growth potential of South Africa, though there is evidence that fiscal prudence and the introduction of a National Credit Control Act (Act No. 34 of 2005) have had the combined beneficial effect of limiting the exposure of the country and its citizens to bad debts and irresponsible lending practices (South Africa, National Credit Regulator, 2008).

Following the first democratic election of 1994, the Government of National Unity (GNU), a multi-party agreement consisting of seven political parties, recognised that unemployment and underemployment would strongly affect the capacity of breadwinners to improve the economic circumstances of their households. The response from the GNU in 1995 was the White Paper on National Strategy for the Development and Promotion of Small Business in South Africa, which sought to encourage circumstances in which small and micro-enterprises could develop: "The stimulation of Small, Medium, and Micro Enterprise (SMMEs) must be seen as a part of an integrated strategy to take the South African economy onto a higher road - one on which our economy is diversified, productivity enhanced, investment is stimulated and entrepreneurship flourishes" (South Africa, Department of Trade and Industry, 1995). In particular, the need for improved access to information was recognised as one of the critical needs of SMMEs. Such information is essential for gaining access to sources of finance, advice on appropriate technology, training and guidance on setting-up, establishing and developing businesses.

A successful SMME start-up requires access to finance, whether as capital from the resources of the entrepreneur or as venture capital from an external source, and it was access to this and to lack of information and training that early-on recognised as problems for entrepreneurs. A recent comment by Rogerson indicates that, despite considerable government intervention and support, these limiting factors remain of major importance: "Better access to finance, skills and business training and more flexible regulations are identified as key strategic elements in supporting the three pillars of promoting entrepreneurship; strengthening the enabling environment; and enhanced competitiveness and capacity at the enterprise level" (2008, p. 62).

Frequent references to the information society have been made by government and other leaders especially since the vocal plea by Thabo Mbeki (then Deputy President) at the G7 Information Society Conference in Brussels in 1995. There he urged rich countries to assist poor countries to enjoy the benefits of the information society (Business Report, 1995). As a consequence, the Information Society and Development Conference was hosted in South Africa in 1996. The theme of the information society has enjoyed prominence ever since then in speeches and statements by government 
leaders. Former Education Minister, Kader Asmal, conceded in a speech in 2002 that the South African government did not have a coherent policy on the information society (Asmal, 2002). He suggested that an information society "involves the integration of the information technology, telecommunications and the information sector" which accompanies the emergence of a new and networked society. He reiterated the government's belief that information communication technologies (ICTs) are "key drivers for economic growth and socio-economic upliftment" (Asmal, 2002). At the inaugural meeting of National Council for Library and Information Services (NCLIS), the Deputy Minister of Arts, Culture, Science and Technology advised that one of the main tasks for NCLIS would be to "integrate local needs and ideals with those of the global information society" (Sonjica, 2004).

There is thus ample evidence of both the need for innovative ways of assisting the development of SMMEs and of recognition by government of the roles that channels for information flow and the availability of sources of relevant and reputable information can play in economic development. However, some commentators have questioned whether the strategies pursued by the South African government have had the desired effect of encouraging and developing small business capacity (Kesper, 2000). Rogerson (2008, p. 65) summarises the additional problems faced by women in South Africa in gaining access to financial institutions and suitable financial products.

\section{The genesis of Library Business Corners}

In 1996, the South African government passed the National Small Businesses Act (South Africa, 1996), later amended in 2003 (South Africa, 2003) and 2004 (South Africa, 2004). This legislation put into effect many of the strategies identified in the White paper on national strategy for the development and promotion of small business in South Africa (South Africa, Department of Trade and Industry, 1995), including the development of a National Small Business Support Strategy. The provisions of the Act included the establishment of a comprehensive service, Ntsika Enterprise Development Agency (later to become part of the Small Enterprise Development Agency (SEDA) as a result of the 2004 amendment to the Act), to become an intermediary between government, the private sector and Service Providers by providing or creating points of access to non-financial information related to markets, training, information services and advice on appropriate technology. It was intended that the development of what were to become know as local business service centres (LBSCs) should act as the immediate point-of-contact for entrepreneurs and local businesses. LBSCs could be established as private organisations, non-governmental organisations or communitybased organisations. However, in a subsequent study, Chalera (2006, p. 183) concluded that the roles of these and the various agencies developed to support SMMEs in South Africa were often confused in the minds of potential clients and providers of major services, such as finance houses. He also noted that there was scepticism at provincial level about the extent of Ntsika's knowledge of the local business communities and about its ability to function effectively (Chalera, 2006, p. 204). This tended to confirm an earlier study by Ladzanil:

The LBSCs, defined in terms of their functions, are owned by the local business people and managed by the local people. Their services include training, marketing and linkages, counseling and referrals and information gathering and dissemination. . . . The major challenges to these centers are in developing SMMEs in rural communities. These SMMEs operate in a sea of poverty and unemployment; most of them are survivalist enterprises; there 
is poor infrastructure, outflow of wealth to larger urban centers and reduced access to markets (Ladzanil, 2001, p. 5).

At the National Small Business Conference, held in 1996, vigorous discussion about the viability of establishing a country-wide network of LBSCs highlighted the opinion that the original plan was considered far too costly to implement.

During subsequent discussions in Cape Town, it was noted that a possible channel for the distribution of information already existed within many communities: the public library network. Providing reliable statistics on the number of "public" libraries in South Africa was, at that time, surprisingly difficult because of inconsistency in definition and the existence in some areas of community-supported, as well municipally supported, services. The Public and Community Libraries Inventory of South Africa (PACLISA) subsequently identified 1,249 public libraries in South Africa (Van Helden and Lor, 2002) whilst a more recent investigation by KPMG identified 1,537 dedicated public libraries (which included 79 mobile libraries) and 88 multipurpose community centres, only some of which contain libraries. Collectively, they provide a network of service points that has the potential to reach urban communities, though the needs of those in rural areas are still largely unmet. The spread of service points is very uneven, with the best provision being found in the Provinces of the Western Cape, Free State, KwaZulu-Natal and Gauteng. There are approximately 30 libraries for every million of the inhabitants of South Africa, a service level that puts the country well below that of other developed countries, and a very low rate of increase in provision (KPMG, 2007, p. 1).

A proposal for a pilot project to establish LBSCs through the public library network was accepted in 1997 for funding by the City of Cape Town. Central to this idea was the recognition that the "core business" of librarians is the dissemination of information, of which business-related information clearly forms part. The Cape Metropolitan Council also accepted a request for support for a similar approach, to be developed by the Cape Town Small Business Centre. The focus, in each case, was on provision of access to information and communication technology-supported services (ICTs), with hardware and network capacity supplied by external providers.

In the Western Cape there are estimated to be over 120,000 small and microenterprises; however, successful development is not easy and each year of the estimated 20,000 people trying to start a new small enterprise, almost half will fail within a short time. Lack of adequate research and consideration of appropriate business information is a significant factor in the failure of many.

Several problems with the idea became apparent: levels of computer awareness were not high amongst the community and many librarians also lacked training in the provision of business information and the use of computers to locate information. Furthermore, the reliability and support for the networking services by the providers was inconsistent. Following a review, it was decided to focus on the provision of business information largely in paper form; however, this strategy also quickly presented problems because of a lack of books and other resources that were relevant to the needs of entrepreneurs and owners of SMMEs. In particular, it was recognised that the reading level of materials often assumed a tertiary education and that much of the material was published only in English or Afrikaans - South Africa has 11 official languages, and although both are widely understood for day-to-day speech across the country, English and Afrikaans are not the home languages of the majority of the population. Additionally, the locus of ownership of the service was also unclear and 
resulted in librarians feeling that they had no role to play in the making of decisions that might affect their abilities to provide salient information for their communities.

A decision was made in 2000 to re-launch the idea, using the name "Library Business Corners" (LBC), and to adopt a "grass roots" approach to provision, with facilitation (as distinct from control) from a central point.

The LBC model has been adopted in other parts of South Africa, such as KwaZulu Natal, Eastern Cape and Limpopo, with the Western Cape team offering advice and guidance on establishment (City of Cape Town, 2002).

\section{Setting up a library business corner}

The practical exemplification of this "grass roots" approach is that the request for the establishment of a Library Business Corner usually comes from librarians. Because of their strong community involvement, they are well-placed to know the needs of their communities and the availability of other sources of information. Thus, the focus is on making relevant business-related information accessible for prospective or existing entrepreneurs in particular communities.

Contact with the LBC team, based in Cape Town, commences the process of establishment. During an on-site visit, a member of the team presents the LBC concept in detail, the resources that can be provided and a suitable location in the library for a dedicated "corner" is identified. Thereafter, a funding application is completed by the librarian-in-charge, together with a request for a list of all the business-related books and other materials that could be made available in the library, within an agreed budget. From this, the librarian-in-charge makes a selection, bearing in mind local needs. The materials are processed on receipt by the LBC team and then delivered to the library. Most of the public libraries in the Western Cape now have LBCs established; many are in small towns.

If an LBC is to assist a community to raise its awareness of self-employment opportunities it must also provide opportunities for training, by identifying members of the community and organisations that can provide workshops and other events at a suitable level. It should also be gathering case studies about entrepreneurship and successful innovations within the communities served. In addition, an LBC should be able to direct enquirers to other local and national sources of information, especially those available through the use of ICTs.

\footnotetext{
A view from the ground

The Western Cape includes 24 municipalities and more than 130 towns and villages, separated by largely rural areas. To aim to support business enterprises and entrepreneurship is a laudable objective but one that is doomed to failure if it is based on the goal of providing contact points in every community. Early on, the difficulty of this model of provision was recognised and it was accepted that a "hub and spoke" approach should be considered. This works by establishing a "hub" at a public library in a large community and linking this "hub" to the "spokes", which represent the services in the smaller communities. By having a clear pattern of referral, requests that cannot satisfactorily be answered at a "spoke" level can be passed to a "hub" and from there, if necessary, to the LBC team in Cape Town or some other suitable information source. This model is attractive because it is less costly and can, potentially, be easier to facilitate. It is also easier to focus in training on the respective roles of services at "hub" and "spokes" and to build confidence in the referral system by regular checks on
} 
performance. Thus, LBC considers its essential role as a provider of a communitybased channel to business-related information.

A further complication is the apparent multiplicity of sources and services that have developed since 1994, many offering apparently similar services to the SMME sector. In an internal LBC paper, Thomas (2007b) has identified the following categories of service:

national government (departments) including legislation, regulations, prescribed procedures, etc.;

provincial government (departments);

district municipalities;

municipalities including local municipal offices;

parastatals including small-business-support agencies;

non-governmental and community-based organisations that actively support small enterprises;

financial institutions and business-service suppliers;

sector associations and chambers of commerce;

education and training suppliers offering small-business-related programmes; and

published books and articles in the SMME field including international publications and comparative studies.

This list includes some that can be regarded as competitors in whole, or in part, for the type of services offered by LBC. Under the provisions of the National Small Business Amendment Act 26 of 2003 (South Africa, 2003), the SEDA took over the functions of the Ntsika Enterprise Promotion Agency and two other agencies. SEDA describes itself as a "delivery network [which] must reach all regions of the country and integrate government-funded small enterprise support across all tiers of government"; furthermore, it states that "The mandate of SEDA is to design and implement a standard national delivery network that must uniformly apply throughout the country" (Small Enterprise Development Agency, 2007). The website contains information of a similar kind to that offered by LBC. The real enterprise development initiative ("Red Door"), which falls under the ægis of the enterprise development subdirectorate of the Western Cape Department of Economic Development and Tourism, has also become established in communities in the Western Cape, including those in marginalised areas. It identifies its role as:

A one-stop shop for new and existing businesses looking for help and advice, from the most basic to the most sophisticated. We aim to:

Help build new businesses;

Help strengthen and develop existing businesses; and

Help create and build more black-owned businesses.

RED Door centres are easy to find in most large communities and towns in the Western Cape. We speak English, Afrikaans and Xhosa and our expert, friendly staff will work with you to analyse your business needs and then develop a customised action plan (Cape Gateway, 2006).

An examination of the resources listed by Cape Gateway as available to local businesses within the Western Cape (Cape Gateway, 2006) reveals that there are 19, organised into three categories (government supported, private sector and non-governmental 
organisation support, information services), which describe accountability rather than the type of service provided (see Table I).

Apart from those that are sector specific (such as Clotex), all are offering information services as part of their portfolios.

Perhaps a multiplicity of sources is to be encouraged since it should increase the probability of a seeker finding some required information. However, extensive studies of information-seeking behaviour (see, for example, Atkinson and Figueroa, 1997) suggest that even those in tertiary education often fail both to follow systematic patterns of searching and to find relevant information. Ikoja-Odongo and Ocholla (2004), in a survey of entrepreneurs in the informal sector of the economy of Uganda, suggested that an appropriate model for information behaviour for this community of users must be grounded on oral traditions and indigenous knowledge and be sensitive to effects of poverty, lack of infrastructure and illiteracy on information-seeking behaviour. The research also highlighted the importance of information repackaging and the use of appropriate media for information provision. From the perspective of the Western Cape, and from that of many areas in South Africa, the conditions found in the Ugandan community also apply and the conclusion must be that providing more channels and resources will not ensure that information does reach the entrepreneurs. Furthermore, it can be argued that the plethora of potential suppliers of information makes the information-seeking endeavours of the entrepreneur more difficult because of confusion over which source to approach.

A particular weakness has been identified through user studies and the sharing of anecdotal evidence from users of LBC services: the lack of business-related material at suitable levels and in a range of indigenous languages. The underlying problem is not solely that of the capacity of indigenous-language publishing houses to respond: it is also the dearth of material written at a level that is appropriate to the circumstances and needs of entrepreneurs and managers of SMMEs. Pallo Jordan, Minister of Arts and Culture, acknowledged the complexity of the issues in an answer to a question in Parliament on the need to support publishing programmes in South Africa in languages other than English and Afrikaans (Jordan, 2005).

Providing material of an appropriate kind and level is recognised within LBC as being of major importance. Although there may be a common set of skills in developing a business plan that can be identified and explained, to gain the credence of aspiring entrepreneurs and managers of SMMEs requires that the framing and exemplification of the skills also be appropriate to their circumstances. To use an example of setting-up a small fishing business to assist a group wanting to set up a vegetable growing business presents an immediate obstacle to understanding, even before the financial and planning aspects have been considered: even though the skills base required may be identical, the process of abstraction from the model is complex. This highlights the need for adjunct roles: those of "re-packager" of information, interpreter and author, or producer, of resources. It is equally clear that, except in a minor way, LBC does not have the capacity to take on either role. Such work requires a multiplicity of publishing skills, including translating ability and copyright clearance, which the team does not possess. It is unrealistic to rely upon the goodwill of those that do have such skills to take on these tasks in a voluntary or community-spirited capacity.

What has become evident is that the list of sources noted by Thomas (2007b) is skewed towards providing channels for the flow of information at community, provincial and national levels. Few sectors on the list see their role as that of producing and re-packaging information; even fewer conceive of it as being to re-package, 


\begin{tabular}{|c|c|c|}
\hline \multirow[t]{5}{*}{$\begin{array}{l}\text { Government } \\
\text { supported }\end{array}$} & Red Door & $\begin{array}{l}\text { One-stop shop for new and existing } \\
\text { businesses looking for assistance and } \\
\text { advice }\end{array}$ \\
\hline & $\begin{array}{l}\text { Tourism Business } \\
\text { Development Unit } \\
\text { Agri-business Support }\end{array}$ & $\begin{array}{l}\text { Advice and support for tourism businesses, } \\
\text { including } \\
\text { Wide variety of support, training and } \\
\text { information for all farmers }\end{array}$ \\
\hline & Umsobomvu Youth Fund & $\begin{array}{l}\text { National government project to create } \\
\text { opportunities for youth employment and } \\
\text { youth entrepreneurship }\end{array}$ \\
\hline & Small Enterprise & $\begin{array}{l}\text { Project of the national Department of trade } \\
\text { and industry to support small businesses. }\end{array}$ \\
\hline & Development Agency & $\begin{array}{l}\text { They offer comprehensive support and } \\
\text { advice on all aspects of running a business, } \\
\text { and provide links to finance providers } \\
\text { Advice, training, networking and exhibition }\end{array}$ \\
\hline \multirow[t]{11}{*}{$\begin{array}{l}\text { Private sector and } \\
\text { non-governmental } \\
\text { organisation support }\end{array}$} & $\begin{array}{l}\text { Cape Craft and Design } \\
\text { Institute }\end{array}$ & $\begin{array}{l}\text { support for any business involved in the craft } \\
\text { and design industry } \\
\text { Training for the clothing and textile } \\
\text { industry, information on legal issues, }\end{array}$ \\
\hline & Clotex & $\begin{array}{l}\text { finance, computer skills and technology } \\
\text { Regional trade association, networking body } \\
\text { and a promotion agency for the ICT }\end{array}$ \\
\hline & Cape IT Initiative & $\begin{array}{l}\text { industry; runs a number of mentoring and } \\
\text { support projects for small IT companies } \\
\text { Specialised investment company for } \\
\text { SMMEs, offering finance, property }\end{array}$ \\
\hline & Business Partners & $\begin{array}{l}\text { management, mentorship, consulting and } \\
\text { on-going business support through } \\
\text { industry-specific units }\end{array}$ \\
\hline & & $\begin{array}{l}\text { Advice and training for entrepreneurs, as } \\
\text { well as helping to find finance } \\
\text { Training and support services }\end{array}$ \\
\hline & $\begin{array}{l}\text { Centre for Innovation } \\
\text { and Entrepreneurship } \\
\text { Entrepreneurship } \\
\text { Development Unit }\end{array}$ & \\
\hline & $\begin{array}{l}\text { Matie Gemeenskapdiens } \\
\text { (Community Service) }\end{array}$ & $\begin{array}{l}\text { Support and training, including basic } \\
\text { business skills, for women entrepreneurs } \\
\text { and people with disabilities }\end{array}$ \\
\hline & Business beat & $\begin{array}{l}\text { Helps entrepreneurs to identify viable } \\
\text { business opportunities and develop their } \\
\text { business skills }\end{array}$ \\
\hline & NICRO Business Centre & $\begin{array}{l}\text { Training and support for people wanting to } \\
\text { start their own small businesses, especially } \\
\text { former offenders, families of offenders and } \\
\text { victims of crime. Finance services and micro } \\
\text { loans are also available }\end{array}$ \\
\hline & $\begin{array}{l}\text { Micro Enterprise Network } \\
\text { of NGOs (MENNGOS) }\end{array}$ & $\begin{array}{l}\text { Training, support and networking for all } \\
\text { small businesses, including a "Women } \\
\text { Supporting Women" network } \\
\text { Trains unemployed people in welding, }\end{array}$ \\
\hline & Zenzele & $\begin{array}{l}\text { woodwork, sewing, catering and tourism. It } \\
\text { helps graduates to form co-operatives, and } \\
\text { also provides business development and } \\
\text { incubation services }\end{array}$ \\
\hline
\end{tabular}

Table 1.

Resources

(continued 


\begin{tabular}{|c|c|c|}
\hline Information services & $\begin{array}{l}\text { Strategic Business } \\
\text { Partnerships for Growth } \\
\text { in Africa (SBP) } \\
\text { BIG News }\end{array}$ & $\begin{array}{l}\text { Available at most libraries in the Western } \\
\text { Cape; each provides a wide range of books, } \\
\text { pamphlets and other information resources, } \\
\text { as well as a place to display business cards } \\
\text { and products } \\
\text { Research and development services to } \\
\text { promote strategic partnerships and a better } \\
\text { regulatory environment for business growth } \\
\text { in Africa; range of useful publications } \\
\text { Independent newspaper and website } \\
\text { specifically to help business owners grow } \\
\text { their businesses and create jobs. Regional } \\
\text { supplements published in Gauteng and the } \\
\text { Western Cape }\end{array}$ \\
\hline
\end{tabular}
Western Cape

Table 1.

translate and produce information in forms suitable to the variety of communities, language needs and business interests in South Africa. Furthermore, it can be argued that few of the potential users of such services will have the time or resources to identify which of these many agencies can best assist.

The foregoing suggests that the range of development strategies to be adopted by LBC is far from clear: should LBC continue independently, collaborate with others, coalesce or, even, cease?

\section{The balanced scorecard}

To gain a perspective on this, the "balanced scorecard" approach, first developed by Kaplan and Norton (1992), was used in a simplified form, to highlight areas for development and problem areas in the operations of LBC.

The essence of the balanced scorecard approach is to examine the work and orientation of an organisation from four "views". The means of conducting a full analysis is, in the first stage, to identify the components of the organisation from the perspective of each view and, in the second stage, to consider how best the position and development within each of these perspectives might be measured and to develop and test suitable means of measurement. Thereafter, data relevant to each perspective are collected and analysed. In a further step, the balance between the perspectives is assessed by considering the measurements and strategy developed with the aim of adjusting activity within each perspective in order to bring the model into balance. In the simplified approach adopted, only the first stage has been conducted as an aid to strategic thought about the work of LBC.

The "views", and the main question each promotes in relation to LBC, may be designated as:

Learning and growth: how can LBC sustain this?

\section{Business process: at what must LBC excel?}

Customer: how does LBC want to be viewed by customers?

Financial: how does LBC want to be viewed by those who support it financially?

There is a basic issue that must be resolved before the analysis can commence: in considering the "views", who is the Customer of LBC? There are three layers that could, potentially, contain its customer base:

the community of entrepreneurs and managers of SMMEs; 
the library staff operating LBCs as part of the public library services to the community; and

the Metropolitan and Provincial managers of these library services.

Furthermore, LBC consists of a small central group (the "LBC team"), that works with librarians, as well as a "points of presence" (POPs) in most of the public libraries of the Western Cape. The team does not "run" the POPs; rather, it services them by working through the librarians who manage the public libraries in the communities. The librarians are, in turn, employed by the Metropolitan or Provincial library authorities. Having previously gained the approval of the library authorities for the concept of LBC, the initiative to establish a POP is "grass roots", coming from the community through the librarian managing the library in the community, but receives final approval from the library authority. The identification of "LBC" by entrepreneurs and managers of SMMEs is thus with the POPs and with the librarians managing the POPs - not with the LBC team.

LBC team activities have been described as "to 'set up' an increasing number of library-based information points in Cape Town as well as countryside libraries in the Western Cape, and to 'supply' them with up-to-date material as well as advice and support for their 'outreach activities' to local entrepreneurs" (Thomas, 2007a). From this, it becomes clear that the community of entrepreneurs and managers of SMMEs is, indeed, the end point of service but that the approach to them by the LBC team is indirect: the immediate customers of the LBC team are the librarians running POPs.

This leaves the question of accountability: the first stage of the "balanced scorecard" approach requires consideration of accountability - in its most basic form, the Financial view - but this can be extended to embrace the general idea of response to stakeholders. Here, the answer is more complicated: since the LBC team supplies resources for service provision it is immediately accountable to those who manage the resources in the community - in this case, the librarians. It is also accountable to the funders - in this case, the Metropolitan and Provincial authorities. The LBC team must also share accountability with those running the POPs for the quality of the service.

As for the Business Process, the LBC team must excel in its selection and supply of resources and with its backup of the POPs for fielding difficult enquiries. Unfortunately, neither aspect is in direct control of the LBC team: the lack of appropriate materials to purchase severely limits what can be selected; however quick and effective the supply process, much of the material will be of doubtful immediate value. The LBC team also requires more specialists in business information if it is to offer full support for POPs.

The reality is that in the near to medium term it is very unlikely that financial support for LBC work will increase; the economic downturn makes this even less likely. The challenge is to create a sustainable service by the LBC team to POPs using the existing monetary resources or, even, a reduced financial base. In such circumstances, it can be argued that the way to sustain the fourth "view" in the balanced scorecard approach - Learning and Development - is to increase the capacity of those at the POPs to use the information resources already to hand, or available at no cost through ICTs. This implies the need for information literacy, both at the level of training library staff and at the level of training librarians to teach information literacy skills in their communities and that training should also encompass some basic understanding of the taxonomy of business information.

An, as yet unanswered question, is whether the LBC team should continue to occupy separate premises: other options include making use of space which might be offered 
by the City of Cape Town Library Service and reconfiguring the team to use teleworking from home offices.

The challenge for those who are part of the supply chain for information is assisting the user to find reputable sources that are relevant in content, level and language: this is a task that requires skilled people making use of appropriate technology. LBC, both its team and through the POPs, has a role to play - but it may need to adjust how it conducts its business.

\section{References}

Asmal, K. (2002), "Closing address by Professor Kader Asmal MP, Minister of Education", paper presented at the Twentieth International Conference on Technology and Education (ICTE) Africa 2002: Learning in the Digital World, Potchefstroom, 2-5 April, available at: www.info.gov.za/speeches/2002/020408346p1002.htm (accessed 20 February 2009).

Atkinson, J.D. and Figueroa, M. (1997), "Information seeking behavior of business students: a research study", Reference Librarian, Vol. 27 No. 58, pp. 59-73, available at: doi: 10.1300/ J120v27n58_07 (accessed 13 February 2009).

Brand South Africa (2007), "SA's booming black middle class", available at: www.southafrica.info/about/people/blackdiamonds-230507.htm (accessed 13 February 2009).

Business Report (1995), "Mbeki seeks on-ramp to the information highway", No. 9, March, p. 23.

Cape Gateway (2006), "Red Door small business advice centres: overview", available at: www.capegateway.gov.za/eng/your_gov/13464\#4 (accessed 13 February 2009).

Chalera, C.S. (2006), "An impact analysis of South Africa's national strategy for the development and promotion of SMMEs", PhD thesis, University of Pretoria, available at: http:// upetd.up.ac.za/thesis/available/etd-05022007-102936/unrestricted/00front.pdf (accessed 20 February 2009).

City of Cape Town (2002), "News report: city libraries provide small business access", available at: www.capetown.gov.za/en/MediaReleases/Pages/CityLibrariesProvideSmallBussAccess.aspx (accessed 20 February 2009).

Ikoja-Odongo, R. and Ocholla, D. (2004), "Information seeking behavior of the informal sector entrepreneurs: the Uganda experience", Libri, Vol. 54 No. 1, pp. 54-66.

Jordan, P. (2005), "Promoting the writing and publication of books in indigenous African languages: response to a parliamentary question on the shortage of books in African languages", 11 April, available at: www.info.gov.za/speeches/2005/05051212451001.htm (accessed 20 February 2009).

Kaplan, R.S. and Norton, D.P. (1992), "The balanced scorecard: measures that drive performance", Harvard Business Review, Vol. 70 No. 1, pp. 71-9.

Kesper, A. (2000), "Failing or not aiming to grow? Manufacturing SMMEs and their contribution to growth in South Africa", Trade and Industry Policy Strategies (TIPS), Working Paper No. 15, Johannesburg, TIPS, available at: www.tips.org.za/files/412.pdf (accessed 20 February 2009).

KPMG Services (Proprietary) (2007), "Status quo report for the Department of Arts and Culture [DAC]", DAC - Public Library Funding Model - Phase 2 [Report 2 of 3]: final, available at: www.dac.gov.za/projects/nclis/DAC\%20-\%20Public\%20library\%20funding\%20model\%20\%20Phase\%202\%20_Report\%202\%20of\%203_\%20final\%20-\%20disclaimer.pdf (accessed 20 February 2009).

Ladzanil, W. (2001), "Small business development in South Africa under the majority rule", paper presented at the Fourteenth Annual Conference of the Small Enterprise Association of Australia and New Zealand (SEAANZ), Wellington. 
Rogerson, C.M. (2008), "Tracking SMME development in South Africa: issues of finance, training and the regulatory environment", Urban Forum, Vol. 19 No. 1, pp. 61-81, available at: doi: 10.1007/s12132-008-9025-x (accessed 20 February 2009).

Small Enterprise Development Agency (SEDA) (2007), "About us - SEDA - who we are", available at: www.seda.org.za/content.asp?sublD1/41 (accessed 20 February 2009).

Sonjica, B. (2004), "Speech by Ms Buyelwa Sonjica, Deputy Minister of Arts, Culture, Science and Technology, at the Inaugural Meeting of the National Council for Library and Information Services (NCLIS), Cape Town", Centre for the Book, 11 March, available at: www.info. gov.za/speeches/2004/04031209461007.htm (accessed 20 January 2009).

South Africa (1996), National Small Business Act (no. 102 of 1996), available at: www.info.gov.za/ acts/1996/a102-96.pdf (accessed 27 July 2007).

South Africa (2003), National Small Business Amendment Act (no. 26 of 2003), Government Gazette 461, available at: www.info.gov.za/gazette/acts/2003/a26-03.pdf (accessed 27 July 2007).

South Africa (2004), National Small Business Amendment Act (no. 29 of 2004), Government Gazette 474, no. 27101, available at: www.info.gov.za/gazette/acts/2004/a29-04.pdf (accessed 20 February 2009).

South Africa, Department of Trade and Industry (1995), White Paper on National Strategy for the Development and Promotion of Small Business in South Africa, Government Printer, Cape Town, available at: www.info.gov.za/speeches/2002/020408346p1002.htm (accessed 20 February 2009).

South Africa, National Credit Regulator (2008), The National Credit Act (no. 34 of 2005), available at: www.ncr.org.za/the_act.html (accessed 13 February 2009).

Statistics South Africa (2006), Mid-year Population Estimates, South Africa, available at: www.statssa.gov.za/publications/p0302/p03022006.pdf (accessed 16 February 2009).

Thomas, W.H. (2007a), "The future of the Western Cape LBC as an evolving Cape Town Cityinitiated project", position paper/discussion document (unpublished).

Thomas, W.H. (2007b), "Informing, advising and mentoring micro-enterprises" (unpublished).

United Nations Development Programme (UNDP) (2008), "Statistical update: South Africa", The Human Development Index: Going Beyond Income, available at: http://hdrstats.undp.org/ 2008/countries/country_fact_sheets/cty_fs_ZAF.html (accessed 12 February 2009).

University of Cape Town (2006), "New study explodes myths about SA's new black middle class", UCT Unilever Institute of Strategic Marketing, available at: www.unileverinstitute.co.za/index.

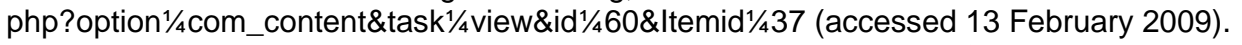

Van Helden, P. and Lor, P. (2002), Public Community Libraries Inventory of South Africa: PACLISA Final Report, National Library of South Africa, Pretoria.

World Bank Group (2008), "Country brief: South Africa", available at: http://go.worldbank.org/ GSBYF92330 (accessed 13 February 2009).

\section{Further reading}

Statistics South Africa (2006), Mid-year Population Estimates, South Africa, available at: www.statssa.gov.za/publications/p0302/p03022006.pdf (accessed 16 February 2009). 